\title{
The Effect of Eight-Weeks Coordination Training on Tennis and Motor Skills Performance on 8-10 Years Children
}

\author{
MINE GÜL ${ }^{1 *}$, DOĞUKAN ÇELIKK ${ }^{2}$ \\ ${ }^{1 *}$ Asistant Professor, Kocaeli University, Faculty of Sports Science, Umuttepe Campus, Izmit, Kocaeli, Turkey. Orcid ID; \\ https://orcid.org/0000-0003-2763-0697 \\ ${ }^{2}$ Kocaeli University, Faculty of Sports Science, Umuttepe Campus, Izmit, Kocaeli, Turkey. Orcid ID: https://orcid.org/0000-0002-4946-4661 \\ Correspondence to Dr. Mine Gül, Email: minegul7@gmail.com, Phone: +905354144172
}

\begin{abstract}
Aim: To examine the effects of coordination applied to 8-10 years old female athletes on tennis and some motor skills.

Metodology: The athletes were randomly divided into experiment and control groups by applying Dewitt-Dugan tennis test, standing long jump, vertical jump, $20 \mathrm{~m}$ speed, T test and square test. In the study, while the control group only participated in club training for 8 weeks, 5 days a week and 60 min.and the experimental group added coordination training education. Data was collected and entered in SPSS 22.0.

Results: There was a significant difference $(p<0.05)$ in the parameters of all measurements of the experimental group in the standing long jump, vertical jump, $20 \mathrm{~m}$ speed, t test and Dewitt-Dugan parameters and no significant change in the square test results $(p>0.05)$. Among the final measurement values of the experimental and control groups, significant differences were found in favor of the experimental group in the values of standing long jump, vertical jump, 20m speed and Dewitt-Dugan parameters, except for the T test and the square test $(p<0.05)$.

Conclusion: It can be said that the 8-week coordination training applied to the experimental group has a positive effect on the motor characteristics and tennis skill, and specific coordination movements added to each unit training can be beneficial for the athletes.

Keywords:Racket Sports, coordination, skill development, training, drills.
\end{abstract}

\section{INTRODUCTION}

Motor skills play a critical role in every stage of life, as well as basic skills such as walking, grasping, throwing and jumping, as well as special skills and sporting skills. It is known that motor skills are not innate, development can take years, and it is known that it has an important place in physical education and physical development programs by creating fun situations with the support of family and social environment. Skill measures also play an important role in performance evaluation ${ }^{1,2,3}$.

Considering modern approaches in the preparation and development of tennis training, it is thought that it will play an important role in improving the coordination ability levels of the players. It will help coaches to plan the sportive physical preparation content more rationally. The implementation of a differentiated approach to the training of young tennis players will contribute to increasing the efficiency of the training process ${ }^{4}$. It is important for the development of the infrastructure athletes in the tennis that the trainers conduct studies on coordination specific to the sports for the development of fine and gross motor skills as well as the basic skills before primary school. It is thought that selection and discovery of athletes at an early age will be a step to success for both the coach and the athlete ${ }^{5}$. It is thought that coordination skills will contribute to skills in the psychomotor development phase as well as sportive performance. Children's perception development and creativity development is also supported in the pre-primary and post-primary periods when the development of psychomotor skills is learned and implemented ${ }^{6}$.

With a successful program that improves coordination, attention should be paid to the acquisition of many different skills. In all phases of the development of coordination, the trainer should strive to use increasingly difficult exercises.
Coordination exercises should be applied at the beginning of the work in order to achieve the desired goals, and only in this way can a high coordination quality be achieved. Since the nervous system's ability to adapt to changing environmental conditions will develop better at early ages, coordination skills are developed more successfully than adults at early ages. In addition to coordination, developing the fundamentals of speed, balance, quickness and speed, which are the basic principles of training science, is important in the development of infrastructure athletes ${ }^{7,8}$.

The development of coordination skills plays an important role in increasing the technical performance of athletes. The necessity of applying hand-eye coordination and general coordination skills in training in racquet sports, sports that require quickness and reaction have been supported in literature studies $9,10,11$.

Tennis is a sport with intense coordinative features and the transfer of knowledge and skills acquired in the past to newly acquired skills during the learning of tennis skills gain importance ${ }^{12}$. Establishing special coordination practices in tennis is important for performance improvement, especially in forehand backhand techniques. Coordination based activities are increasing in the mobility or relocation of tennis players $^{13}$. Coordination skills have an important place in the tennis game. It is important to develop athletic skills at an early age. Coaches working with young athletes should integrate tennis specific coordination training into tennis technical and tactical training. In addition, these exercises make training for young athletes more enjoyable, useful and target-oriented ${ }^{14,15}$. It has been stated that conditioning training to be applied to young tennis players has an effect on strength, balance strength, endurance and tennis skills, and a planned training may help in preventing possible injury in athletes ${ }^{16,17}$. 


\section{MATERIALS AND METHOD}

This study was applied with 8-10 year old female students playing tennis. Measurements were performed following the approval of the Ethics Committee and carried out in accordance with the Declaration of Helsinki. After the first measurements, the athletes were randomly divided into 2 groups as control $(n=8)$ and experiment $(n=8)$. The age of the experiment group was $9.25 \pm 0.74$ years, their height was $1.36 \pm 6.42 \mathrm{~cm}$ and their weight was $33 \pm 92 \mathrm{~kg}$, and the age of the control group was $9.25 \pm 0.88$ years and height was $1.35 \pm 6.09$. $\mathrm{cm}$ and their weight was determined as $32 \pm 4.47 \mathrm{~kg}$.

Training procedure: All athletes participated in club tennis training education for 8 weeks, 5 days a week for 60 minutes, and in addition to these trainings, 15 minutes of planned coordination drills were applied to the experment group. The control group only participated in club tennis training. Before each training, the athletes were given 15 minutes of in-court running, fun active warm-up movements and stretching movements. In trainings, 4 different coordination skills (floor ladder, training skates, low barrier materials and in-court coordination drills were applied) by planning both individual and fun team drills of the athletes in order to reduce the monotony in each unit training. In addition to the tennis skills development goals of the athletes in the trainings, the transition to coordination skills was aimed, so each unit training was implemented with entertaining tennis content.

Measurements: Square Test:There was performed sprint from 1st to 2nd cone; side-by-side running from 2nd cone to 3 rd cone; back running from the 3rd to the 4th cone; sprint from the 4th to the 1st cone. The time is recorded with the Stopwatch.

T-Test: Athletes touch the cones by performing A-B straight run, $B-C$ side run, $C-D$ side run, D-B horizontal run, and $B-A$ back run in the "T" shape of the ABCD cones. Stopwatch starting at $A$ is stopped at cone $A$ again (The distance between the $A$ and $B$ cones was $9 \mathrm{~m}$ and $35 \mathrm{~cm}$; the distance between the cones $B$ and $C$ was $4 \mathrm{~m} 65 \mathrm{~cm}$; the distance between the cones $B$ and $D$ was $4 \mathrm{~m} 65 \mathrm{~cm})^{19,20,21}$.

Standing Long Jump: The student crouches on the ground and jumps forward with maximum effort without waiting. The flight distance between the last point the heel touches and the jump line is recorded where it falls. Vertical Jump: The athlete lifts its arm up and the top point its fingers reached is marked. The athlete then kneels on its knees and jumps and touches the highest point it can reach with its finger. The difference between the height marked before the jump and the jump height is recorded.

20 M Speed: The test requires a track or non-slippery flat surface. The 30-meter section of the runway is marked with cones. Athletes wait in the ready section at the marked starting point. As soon as the athlete feels ready, he runs 20 $\mathrm{m}$ with his exit. The grade was determined by taking the better than 2 degrees with a running photocell device ${ }^{21}$.

Dewitt Dugan: It is divided into sections like test, serve, serve to board, forehand and backhand shot and hit strike. Serve:10 hits are requested. The valid balls of the athlete are evaluated with full points and invalid ones with 0.5 points. Serve to Board: In hoop consisting of 5 circles (height; $1.5 \mathrm{~m}$; the diameter of the circle in the middle is 30 cm- 9 points; the diameter of the second circle is $90 \mathrm{~cm}-7$ points-; the diameter of the third circle is $150 \mathrm{~cm}-5$ points; the diameter of the fourth circle is $210 \mathrm{~cm}-3$ points; the diameter of the outermost circle is $270 \mathrm{~cm}$.) The subject hits 5 serves from the board at a distance of $12.5 \mathrm{~m}$. BackhandForehand: 10 or 15 balls are thrown at side of forehand and the same number of from backhand balls. 1 point is awarded for the received ball (Rally) on the tennis court. Hit: The subject shoots at a designated area on the wall and tries to throw it to the same area when the ball comes back. The score is the sum of points after 5 shots. Speed:The athlete throws the ball to the wall for 1 minute by using the desired stroke technique, at least $3 \mathrm{~m}$ from the wall. The score is determined by the number of balls hitting the wall during this time ${ }^{22}$.

Statistical analysis: In order to determine whether there is a statistically significant difference between the results of the first and post test measurements of the groups, Wilcoxon test was applied to non parametric tests for intra group comparisons between the descriptive statistics and non parametric tests. SPSS 22.0 statistical package program was used to analyze the data and the level of significance was determined as $\mathrm{p}<0.05$.

\section{RESULTS}

Table 1: First-last measurements analysis of research groups

\begin{tabular}{|c|c|c|c|c|c|c|c|c|}
\hline \multirow{2}{*}{ tents } & \multirow[b]{2}{*}{$\mathbf{N}$} & \multirow[b]{2}{*}{ Tets } & \multicolumn{3}{|c|}{ Control $(n=8)$} & \multicolumn{3}{|c|}{ Experiment $(n=8)$} \\
\hline & & & $\mathrm{X} \pm \mathrm{Ss}$ & Difference (\%) & $\mathbf{P}$ & $\mathrm{X} \pm \mathrm{Ss}$ & Difference (\%) & $\mathbf{P}$ \\
\hline \multirow{2}{*}{$\begin{array}{l}\text { Standing Long } \\
\text { Jump }(\mathrm{cm})\end{array}$} & 16 & First & $87,12 \pm 0,26$ & \multirow[b]{2}{*}{0,63} & \multirow{2}{*}{0,11} & $87,87 \pm 0,26$ & \multirow[b]{2}{*}{2,38} & \multirow{2}{*}{$0.04^{*}$} \\
\hline & 16 & Last & $87,75 \pm 0,39$ & & & $90,25 \pm 0,39$ & & \\
\hline \multirow{2}{*}{ Vertical Jump (cm) } & 16 & First & $26,25 \pm 1,84$ & \multirow{2}{*}{0,31} & \multirow{2}{*}{0,50} & $26,68 \pm 1,71$ & \multirow{2}{*}{1,25} & \multirow{2}{*}{$0.04^{*}$} \\
\hline & 16 & Last & $26,56 \pm 1,57$ & & & $27,93 \pm 1,81$ & & \\
\hline \multirow{2}{*}{$\begin{array}{l}20 \mathrm{~m} \text { Speed } \\
\text { (s) }\end{array}$} & 16 & First & $4,07 \pm 0,07$ & \multirow{2}{*}{$-0,01$} & \multirow{2}{*}{0,50} & $4,07 \pm 0,07$ & \multirow{2}{*}{$-0,19$} & \multirow{2}{*}{$0.04^{*}$} \\
\hline & 16 & Last & $4,06 \pm 0,07$ & & & $3,88 \pm 0,06$ & & \\
\hline \multirow{2}{*}{ T Test (s) } & 16 & First & $11,98 \pm 2,99$ & \multirow{2}{*}{$-0,05$} & \multirow{2}{*}{0,77} & $12,37 \pm 3,75$ & \multirow{2}{*}{$-1,15$} & \multirow{2}{*}{$0.04^{*}$} \\
\hline & 16 & Last & $11,93 \pm 0,26$ & & & $11,22 \pm 3,45$ & & \\
\hline \multirow{2}{*}{ Square Test (s) } & 16 & First & $13,08 \pm 0,39$ & \multirow{2}{*}{$-0,1$} & \multirow{2}{*}{0,33} & $13,37 \pm 2,56$ & \multirow{2}{*}{$-0,56$} & \multirow{2}{*}{0.07} \\
\hline & 16 & Last & $12,98 \pm 1,71$ & & & $12,81 \pm 2,90$ & & \\
\hline \multirow{2}{*}{$\begin{array}{c}\text { Dewitt-Dugan Test } \\
\text { (Point) }\end{array}$} & 16 & First & $2,50 \pm 0,74$ & \multirow{2}{*}{0,12} & \multirow{2}{*}{0,66} & $2,62 \pm 1,06$ & \multirow{2}{*}{$-0,88$} & \multirow{2}{*}{$0.02^{*}$} \\
\hline & 16 & Last & $2,62 \pm 0,76$ & & & $3,50 \pm 0,93$ & & \\
\hline
\end{tabular}


Table 2: Final measurement analysis of control and experiment group

\begin{tabular}{|c|c|c|c|c|c|}
\hline \multirow[b]{2}{*}{ Last Measurements } & \multirow[b]{2}{*}{$\mathbf{N}$} & \multirow{2}{*}{$\begin{array}{c}\text { Control } \\
\mathrm{X} \pm S s\end{array}$} & \multirow{2}{*}{$\begin{array}{c}\text { Experiment } \\
\mathrm{X} \pm \mathrm{Ss}\end{array}$} & \multirow[b]{2}{*}{ Difference (\%) } & \multirow[b]{2}{*}{$\mathbf{P}$} \\
\hline & & & & & \\
\hline Standing Long Jump (cm) & 16 & $87,75 \pm 0,23$ & $90,25 \pm 0,40$ & 2,5 & $0.04^{*}$ \\
\hline Vertical Jump(cm) & 16 & $26,56 \pm 1,57$ & $27,93 \pm 1,81$ & 1,37 & $0.02^{*}$ \\
\hline 20 m Speed (s) & 16 & $4,06 \pm 0,10$ & $3,88 \pm 0,07$ & 0,18 & 0.07 \\
\hline T Test (s) & 16 & $11,93 \pm 1,70$ & $11,22 \pm 2,20$ & 0,71 & 0.07 \\
\hline Square Test (s) & 16 & $12,98 \pm 0,23$ & $12,81 \pm 0,40$ & 0,17 & 0.12 \\
\hline Dewitt-Dugan Test (Point) & 16 & $2,62 \pm 1,27$ & $3,50 \pm 1,71$ & 0,88 & $0.04^{*}$ \\
\hline
\end{tabular}

As seen in table 1, statistically significant difference was not found in the first and last measurement analysis of the control group athletes in standing long jump, vertical jump, $20 \mathrm{~m}$ speed, T test, Square test and tennis skill Dewitt-Dugan test $(p>0.05)$. However, it was determined in the results of the averages that some motoric properties of tennis skills were improved arithmetically. In the analysis results, there was a significant difference experimental group standing long jump ( $p=0.042)$, vertical jump ( $p=$ $0.044), 20 \mathrm{~m}$ speed test $(p=0.045)$, T test $(p=0.049)$ and Dewitt-Dugan tennis skill test $(p=0.020)(p<0.05)$.

As seen in table 2, the intergroup final analysis results of the athletes participating in the study, as a result of final measurement analysis, a significant difference was found standing long jump by standing in favor of the experiment group $(p=0.042)$, vertical jump $(p=0.022)$ and DewittDugan tennis skill test $(p=0.036)(p<0.05)$. Although there was an improvement in favor of the experiment group in terms of average values in $20 \mathrm{~m}$ speed, T test and square test results, no significant difference was found ( $p>0.05)$.

\section{DISCUSSION}

In the study, the effects of 8 weeks, 5 days a week and 60 minutes of tennis training and coordination training education on tennis skills and some motoric properties were investigated. As a result of the data obtained, the control group who only did tennis training was determined the difference between the first and last measurements of the standing long jump of $0.63 \%$, vertical jump difference $0.31 \%, 20 \mathrm{~m}$ speed test difference $-0.01 \%$, T Test difference $-0.05 \%$, Square test difference $-0.1 \%$ and Dewitt-Dugan test difference $0.12 \%$. and a little improvement has been achieved in all its parameters.

The difference in the first and last test of the experiment group was determined the difference between the first and last measurements of the standing long jump $2.38 \%$, vertical jump difference $1.25 \%, 20 \mathrm{~m}$ speed test difference $-0.19 \%$, T test difference $-1.15 \%$, square test difference $-0.56 \%$ and Dewitt-Dugan tennis skill test difference $-0.88 \%$. There was a significant difference in all data except for the Square test from the measurements $(p<$ 0.05). When the final measurement analysis of the control and experiment groups were examined, statistically significant differences were found in the standing long jump (2.5\% difference), vertical jump (1.37\% difference) and Dewitt-Dugan test $(0.88 \%$ difference $)$ in favor of the experiment group $(p<0.05)$. In line with the results obtained, it was determined that the basic motor skills improved by standing, long jump and vertical jumping skills and tennis skills. It is thought that these skills can have an important place in basic tennis training and that basic tennis training applied together with coordination training can contribute to the training of infrastructure athletes. Results supporting the research were found in the literature research results.

Altınkök, in his research on the effect of coordination and movement training applied to preschool children on some motor skills, as a result of 12 weeks of training, the control group children's skills, long jump, tennis ball throwing, sprint, flexibility, vertical jumping, running coordination and static balance skills, it was determined that there was no significant difference, but there was a significant difference in all parameters in the experimental group children $(p<0.05)^{23}$. Looking at the last measurements, it was found that all motor skill measurements showed a significant difference in favor of the experiment group and Ballı, in her study with children aged 5-6, found a significant difference between the pre and last tests values of some motoric features of balance, standing long jump, catching and throwing tennis ball tests $(p<0.05)^{24}$.

Suna et al., stated that 8-week coordination training programs applied to tennis players aged 10-12 increased the balance, agility and speed parameters, and contributed positively to the performance as a result of the coordination training of male tennis players in adolescence ${ }^{25}$, Gökgönül, in her study on 9-12 age group tennis players, stated that tennis training during the competition period has effects on the coordination development of the athletes ${ }^{26}$, and in the study that examined the pre-competition agility performances of Altınkök and Ölçücü's, 10-year-old male tennis players, the tennis players showed a significant difference in their pre-competition agility performances $(p<$ $0.05)^{27}$. Radwan, in her study on table tennis players, organized for the development of coordination skills, included athletes under 12 years of age. Trainings were applied for 3 months, 3 days a week. The coordination skills of the experiment and control groups were measured as a result of the trainings, and it was concluded that the experiment group improved compared to the control group ${ }^{11}$. Ölçücü et al.,in their study examining the factors affecting tennis skill in 10-14 year-old children, stated that there was a high correlation between the coordination tests of tennis skill tests and that a 6-week recreational tennis training period contributed to the development of coordination characteristics ${ }^{7}$.

Gül et al.,conducted a study on the effects of tennis and reaction training applied to $12-14$ year-old male students on their tennis skills, they concluded that there was a statistically significant difference in tennis skills (DewitDugan, Wall Catch Test) in the experiment group as a result of the reaction and tennis training, and there were significant differences in the service and backhand tests in the control 
group ( $p<0.05)$. In the last measurements of the two groups, a difference was detected in the service and forehand tests in favor of the experiment group $(p<0.05)^{28}$. Ayan and Mülazımoğlu, determined the physical characteristics of 8-10-year-old children in talent selection ${ }^{29}$, and Karagöz et al., found that the vertical jump values of male athletes were significantly different than girls in their study on mini tennis players $(p<0,05)^{12}$. Aslan et al., concluded that the coordination development of girls is affected by age differences and that the coordination development of children between the ages of $10-11$ is more effective ${ }^{30}$

Morales et al., in their study on the effect of tennisspecific coordination drills applied to tennis players aged 1518 on forehand and backhand strike technical skills, concluded that the determined skills had a positive effect on technical strokes and also on their mobility depending on the coordination ${ }^{13}$. Zetou et al., conducted a study on the effect of coordination training on their tennis skills by doing 5minute coordination skills before tennis training for 4 drills for 8 weeks (athletes with a 1-year tennis background), they concluded that it has a positive effect on skill learning $(p<$ $0.05)^{31}$.Guillamon et al., in their research examining the relationship between academic performance and motor coordination skills of 6-9 year old students, determined that there is a direct relationship. It was concluded that students with good academic performance also have a better motor coordination skills.It has been stated that the increase in physical activity opportunities can support the academic development of students ${ }^{32}$.

\section{CONCLUSION}

As a result, it was determined that the coordination exercises applied in the study had an effect on the jumping skill, forehand and backhand hitting skills, and there was no significant difference between the groups in $20 \mathrm{~m}$ speed, $\mathrm{T}$ test and square test results. It can be said that athletes' new start to tennis is due to the fact that their speed and quickness skills are not developed in different direction runs, considering that they may only attend tennis lessons in terms of sports activities. As a result, it can be said that coordination training education applied to female athletes aged 8-10 has an effect on some motoric features and tennis skills.

Acknowledgement: Both authors contributed to the conception and design of the study. This Paper was orally presented at $9^{\text {th }}$ International Physical Education Teachers and Sports Instructors Congress held on 19-22 October 2017 in Antalya.

\section{REFERENCES}

1- Voelcker-Rehage, C. Motor-Skill Learning İn Older Adults-A Review Of Studies On Age-Related Differences. Eur. Rev. Aging Phys. Act.2008; 5: 5-16

2- Clark, J. On The Problem Of Motor Skill Development. Journal Of Physical Education, Recreation \& Dance. Joperd. 2007;78(5): 39-44. Doi: 10.1080/07303084.2007.10598023.

3- Sánchez-Miguel, P.A., Leo, F.M., Sánchez-Oliva, D., Amado, D. \& García-Calvo, T. The Importance of Parents' Behavior in their Children's Enjoyment and Amotivation in Sports. Journal of Human Kinetics.2013;36: 169-177. DOI: 10.2478/hukin2013-0017.
4- Kozak, A.M. \& İbraimova, M.V. Constructıon Of Traınıng Process Of Tennıs Players Aged 5-6 Years, Takıng Into Account The Specifics Of The Development And Control Of Their Coordination Skılls. Physical Education Of Students.2014;

Doi:10.15561/20755279.2014.0604.

$6(1): 17-23$

5- $\quad$ Eren, E., Müniroğlu, R.S. \&Özer, U. Examination Of Visual And Auditory Reaction Times Of Licensed Tennis Players In Different Age Groups. International Journal Of Cultural And Social Studies (Intjcss).2017; 3(2): 343-352.

6- Kılıçgün, M.K. \& Kılıçkaya, A. The Impact Of Weaving Training On 6-Year-Old Children's Two-Handed Use And Hand-Eye Coordination Skills, Gefad / Gujgef. 2018;38(2): 449-467. Doi.Org/10.17152/Gefad.377011.

7- Ölçücü, B., Canikli, A., Ağaoğlu, S. \& Erzurumluoğlu, A. Evaluation Of Factors Affected On Improvements Of The Tennis Skills In Children 10-14 Years Old. Atatürk Unıversity Ournal Of Physical Education And Sport Sciences.2010; 12 (2): 1-11.

8- Erman, K.A., Şahan, A. \& Küçükkaya, A. The Effect Of One And Two-Handed Backhand Strokes On Hand-Eye Coordination İn Tennis. Procedia - Social And Behavioral Sciences.2013; $\quad$ 93: 1800

1804.Doi:10.1016/J.Sbspro.2013.10.120.

9- Lech, G., Jaworski, J., Lyakh, V. \& Krawczyk, R. Effect of the Level of Coordinated Motor Abilities on Performance in Junior Judokas, Journal of Human Kinetics.2011; 30: 153 - 160, Doi:10.2478/v10078-011-0083-0.

10- Patel, B. \& Bansal, P. Effect Of 4 Week Exercise Program On Hand Eye Coordination. International Journal Of Physical Education, Sports And Health.2018; 5(4): 81-84.

11- Radwan, S.G. The Impact Of Development Of The Special Coordination Abilities On The General Skill Ability For Table Tennis Juniors Under 12 Years Old. International Journal Of Science Culture And Sport.2014;2(2): 30-42, Doi: 10.14486/ljscs71

12- Karagöz, Ş., Erdoğmuş, M., Celepaksoy, F., Bozlak, K. \& Alkan, F. Inspection Of The Affects Of Some Physical And Physıological Parameters On Groundstroke Performances Of Junıor Tennıs Players, Niğde University Journal Of Physical Education And Sport Sciences.2015; Sipecial İssue, 9: 19-25.

13- Morales, S.C., Cevallos, E.C. \& Benitez, E.C. Increase İn The Effectiveness Of Technical Displacement İ Tennis Players Through Specific Coordination Exercises. Lecturas Educación Física Y Deportes.2016;21(218): 1-10.

14- Tsetseli, M., Malliou, V., Zetou, E., Michalopoulou, M. \& Kambas, A. The Effect Of A Coordination Training Program On The Development Of Tennis Service Technique. Byology Of Exercise.2010;6(1): 29-36.

15- Gül, M., Gül, K.G. \& Aydın, R. The Effect Of Tradıtıonal Teachıng Approach And Tactıcal Game Approach On Tennıs Skıll. Turkısh Studies Educational Science.2019; 14(5): 23652376. Dol: 10.29228/Turkishstudies.38206

16- Fernandez-Fernandez, J., Ellenbecker, T., Sanz-Rivas, D., Ulbricht, A. \& Ferrauti, A. Effects Of A 6-Week Junior Tennis Conditioning Program On Service Velocity. Journal Of Sports Science And Medicine.2013; 12: 232-239.

17- Miller, M.G., Herniman, J.J., Ricard, M.D., Cheatham, C.C. \& Michael, T.J. The Effects Of A 6-Week Plyometric Training Program On Agility. Journal Of Sports Science \& Medicine.2006;5(3): 459-465.

18- Karacabey, K. Sport Performance And Agility Tests, International Journal Of Human Sciences.2013; 10(1): 16931704.

19- Pauole, K., Madole, K., Garhammer, J., Lacourse, M. \& Rozenek, R. Reliability And Validity Of The T-Test As A Measure Of Agility, Leg Power, And Leg Speed In CollegeAged Men And Women. Journal Of Strength And Conditioning Research.2000; 14(4): 443-450. 
20- Haj-Sassi, R., Dardouri, W., Gharbi, Z., Chaouachi, A., Mansour, H., Rabhi, A. \& Mahfoudhi, M.E.Reliability And Validity Of A New Repeated Agility Test As A Measure Of Anaerobic And Explosive Power. Journal Of Strength Conditioning Research.2011.; 25(2): 472-480. Doi.Org/10.1519/Jsc.0b013e3182018186.

21- Behdar,i R. Investigation Of Branch-Specific Ability Levels And Physical Profiles Of 9-12 Years Male Table Tennis Athletes. Gazi University, Institute Of Educational Sciences Department Of Physical Education And Sports. Unpublished Master's Thesis, Ankara.2011.

22- Köktaş, E. Investigating The Ability Levels Of Children Suitable For Sports, Body Mass Indexes According To Tennis Branch (Konya Province Example), Selçuk University Institute Of Health Sciences, Unpublished Master's Thesis, Konya.2013.

23- Altınkök, M. The Effects Of Coordination And Movement Education On Pre School Children's Basic Motor Skills Improvement. Universal Journal Of Educational Research.2016;4(5): 1050-1058.

24- Ballı, Ö.M. Investigation Of The Effect Of Gymnastics Training Program On Motor Development For 5-6 Age Group Children. Ankara University, Institute Of Science, Department Of Home Economics, Unpublished Doctorate Thesis, 126. Ankara. 2006.

25- Suna, G., Beyleroğlu, M., Alp, M. \& Yalçın, S. Investıgatıng The Effects Of Coordınatıon Traınıngs On Velocıty, Balance And Agılıty Features Of Tennıs Kıds Internatıonal Refereed Academıc Journal Of Sports, Health And Medical Sciences.2016; 20: 13-23.
26- Gökgönül, N. The Examination Of Seasonal Power Changes And Changes in Some Physiological Parameters Of Little Tennis Players (9-12 Years) During The Competition Period. Kırıkkale University, Institute Of Health Sciences, Physical Education And Sports Department, Master's Thesis. Kırıkkale.2008.

27- Altınkök, M. \& Ölçücü B. The Effects Of Coordination And Movement Education On Pre School Children's Basic Motor Skills Improvement. Selçuk University Journal Of Physical Education And Sport Science.2012;14(2): 273-276.

28- Gül, M., Gül, K.G. \& Bulat, A. The Effect Of Reaction Exercises On Tennis Skill And Coordination. Journal Of Academic Sports Research, Special Issue. 2018; 2: 326-330.

29- Ayan, V. \& Mülazımoğlu, O. Talent Selectıon In Sports And Assessment Of The Physical Characteristics And Some Performance Profiles Of Female Chıldren Between 8-10 Years-Old In Guidance To Sports (Ankara Sample). Nigde University Journal Of Physical Education And Sport Sciences.2010; 4(3): 152-159.

30- Aslan, C.S., Özer, U. \& Dalkıran, O. Investigation Of Coordination And Reaction Characteristics Of Girls According To Age Variable. Makü Journal Of The Institute Of Health Sciences.2016; 4(1): 27-33.

31- Zetou, E., Vernadakis, N., Tsetseli, M., Kampas, A. \& Michalopoulou, M. The Effect Of Coordination Training Program On Learning Tennis Skills. The Sports Journal.2012; 45: 1-9.

32- Guillamon, A.R., Canto, E.G. \& Garcia, H.M. Motor Coordination And Academic Performance In Primary School Students. Journal Of Human Sport \& Exercise.2021;16(2): 247-260, Doi:10.14198/jhse.2021.162.02. 